\title{
WHY IS THERE A HOME BIAS? AN \\ ANALYSIS OF FOREIGN PORTFOLIO \\ EQUITY OWNERSHIP IN JAPAN
}

\author{
Jun-Koo Kang \\ René M. Stulz
}

Working Paper No. 5166

\author{
NATIONAL BUREAU OF ECONOMIC RESEARCH \\ 1050 Massachusetts Avenue \\ Cambridge, MA 02138 \\ July 1995
}

We are grateful for comments from Marianne Baxter, Eric Falkenstein, David Mayers, Stewart Myers, Tim Opler, Jim Poterba, Robert Shiller, Dick Thaler, Raman Uppal, participants at the February 1995 Meeting of the NBER Behavioral Finance Group and at a seminar at the Ohio State University, and for useful conversations with Ingrid Werner. This paper is part of NBER's research programs in Asset Pricing and Corporate Finance. Any opinions expressed are those of the authors and not those of the National Bureau of Economic Research.

(C) 1995 by Jun-Koo Kang and RenE M. Stulz. All rights reserved. Short sections of text, not to exceed two paragraphs, may be quoted without explicit permission provided that full credit, including $\odot$ notice, is given to the source. 


\title{
WHY IS THERE A HOME BIAS? AN \\ ANALYSIS OF FOREIGN PORTFOLIO EQUITY OWNERSHIP IN JAPAN
}

\begin{abstract}
This paper uses data on foreign stock ownership in Japan from 1975 to 1991 to examine the determinants of the home bias in portfolio holdings. Existing models of international portfolio choice predicting that foreign investors hold national market portfolios or portfolios tilted towards high expected return stocks are inconsistent with the evidence provided in this paper. We document that foreign investors overweight shares of firms in manufacturing industries, large firms, firms with good accounting performance, firms with low unsystematic risk, and firms with low leverage. Controlling for size, there is evidence that small firms that export more have greater foreign ownership. Foreign investors do not perform significantly worse than if they held the Japanese market portfolio, however. After controlling for firm size, there is no evidence that foreign ownership is related to expected returns of shares. We show that a model with size-based informational asymmetries and deadweight costs can yield asset allocations consistent with our evidence.
\end{abstract}

Jun-Koo Kang

Graduate School of Management

University of California, Riverside

Riverside, CA 92521
René M. Stulz

Department of Finance Fisher College of Business The Ohio State University 1775 College Road, Room 314 Columbus, OH 43210 and NBER 


\section{Section 1. Introduction.}

Over the last twenty-five years, we have seen a dramatic decrease in obstacles to international portfolio investment. Twenty-five years ago, most countries had restrictions on foreign exchange transactions that limited cross-border portfolio investment. Few developed countries have such restrictions now and many emerging countries are eliminating them. Often, countries would forbid inbound foreign portfolio investment altogether. Now, few countries do so, but many countries still have limitations on foreign ownership. Finally, the lack of tax harmonization meant that foreign investors often would find it difficult to get refunds or credits for taxes paid abroad. This is less of a problem now. This evolution does not mean that all obstacles have disappeared. Nevertheless, investors in most countries can now invest abroad through mutual funds and even direct ownership of foreign shares more easily than they could twenty-five years ago.

Many financial economists have noticed that even though the barriers to international investment have fallen dramatically, foreign ownership of shares is still extremely limited and much smaller than one would expect in the absence of barriers to international investment. ${ }^{1}$ In particular, if investors care only about the mean and the variance of the real return of their invested wealth, and if barriers to international investment are as small as many observers suggest, one would expect investors, as a first approximation, to hold the world market portfolio of stocks. All the available data on ownership of shares shows that shares are mostly held by domestic residents, at least for large countries such as the U.S. and Japan. Several explanations have been suggested for this socalled home bias in portfolios, but so far no explanation seems to be generally accepted.

All the existing investigations of the home bias use country-wide data rather than firmspecific data. In other words, we know that foreign investors hold too few Japanese shares, but we

${ }^{1}$ See French and Poterba (1991), Cooper and Kaplanis (1994), and Tesar and Werner (1995) for papers that document this phenomenon. 
do not know how their holdings in Japan are divided among shares. In this study, we provide new insights into the home-bias paradox by using disaggregated data for Japan. Although foreign investment in Japan is interesting on its own merits, Japan also happens to be the only large country that we know of where detailed data on holdings by foreign investors are available. In many countries, some shares cannot be bought by foreign investors or can only be bought by foreign investors. ${ }^{2}$ For these countries, therefore, one can get an estimate of shares held by foreign investors, but these estimates reflect binding constraints on foreign ownership. In the case of Japan, the foreign ownership constraints are not binding and therefore the data on foreign ownership reflects the choices of foreign investors. We use a dataset that provides foreign ownership for individual firms in Japan for a period of seventeen years.

The most robust result we find is that foreign investors invest primarily in large firms: on average, they hold $7.66 \%$ of the equity of the firms in the top size quintile, in contrast to $1.80 \%$ of the equity of firms in the smallest size quintile. Throughout our sample period, foreign investors in Japan overweight holdings of firms in manufacturing industries, firms with good accounting performance, firms with low leverage, firms with high market-to-book ratios, and firms with low unsystematic risk relative to the holdings of the Japanese market portfolio. For a subset of firms, we have data on the ratio of exports to total sales. We find that there is greater foreign ownership for small firms that have a high exports to sales ratio, but that the exports to sales ratio is not important for foreign ownership in large firms.

The home-bias literature has emphasized that investors do not hold the world market portfolio. We show that, in addition, when investors invest outside their home country, they do not hold the market portfolio of the countries in which they invest. The evidence presented in this paper is inconsistent with simple explanations of the home bias that focus on obstacles to holding foreign

\footnotetext{
${ }^{2}$ See Stulz and Wasserfallen (1995) for an analysis of foreign ownership restrictions.
} 
shares that are common to all shares in a country. We show, in the context of a mean-variance model, the type of barriers to international investment that can explain a home bias as well as the relative holdings of foreign securities. In particular, for a model with information asymmetries between domestic and foreign investors to be consistent with the data, it must be that these information asymmetries are smaller for large firms than for small firms.

The paper proceeds as follows. In Section 2, we review the literature on the determinants of foreign portfolio investment. In Section 3, we present a simple model of portfolio holdings within a foreign country. Section 4 describes our data and provides summary measures of foreign investment in Japan per year for our sample period. In Section 5, we show univariate evidence on the crosssectional variation in ownership. We investigate the determinants of foreign ownership using multivariate regressions in Section 6. In Section 7, we study whether foreign ownership is related to the ratio of exports to total sales for a subset of firms. Section 8 evaluates the performance of foreign investors in Japan relative to the performance of the market. Section 9 analyzes whether foreign ownership helps explain the cross-sectional variation of returns. In Section 10, we show the implications of our evidence for models of international portfolio choice. A conclusion is provided in Section 11.

\section{Section 2. The determinants of foreign portfolio investment: A review of the literature.}

Since the late 1960s, it is well-known that investing abroad reduces the variance of a portfolio because foreign shares exhibit a low correlation with domestic shares. Although much of this literature focuses on the perspective of a U.S. investor, this general finding holds for investors everywhere. This literature focuses on the variance reduction resulting from international diversification and generally assumes that international diversification has no significant effect on a portfolio's expected return. With this assumption, this literature implies that international diversification unambi- 
guously improves the performance of the portfolio of an investor who ranks portfolios according to their mean and variance of return.

In the presence of barriers to international investment, it is possible for international diversification to reduce the variance of a portfolio's return and to reduce its mean retum as well. This implies that the studies that focus on the variance reduction benefits of international diversification are not by themselves sufficient to make the case for international diversification. To make that case, one has to argue that expected returns are such that the variance reduction benefit of international diversification is not offset by lower expected returns. One way to make the case for international diversification is to show that the domestic market portfolio is an inefficient portfolio when investors are allowed to hold foreign assets as well as domestic assets. This is a hard case to make because there are multiple barriers to international investment that are difficult to identify and whose impact varies across investors. Nominal returns on foreign shares may therefore not correspond to the returns that accrue to non-resident investors. By all accounts, though, these barriers have fallen dramatically over the last twenty-five years, so that one would have expected a substantial increase in foreign investment.

Many papers have recently pointed out that despite this decrease in barriers to intemational investment, investors allocate only a very small fraction of their portfolio to foreign investments. French and Poterba (1991) and Cooper and Kaplanis (1994) argue that to explain the observed portfolio allocations of investors, barriers to international investment would have to be more substantial than most observers seem to think they are. In particular, they suggest that these barriers would have to be much larger than withholding taxes which often are mentioned as the most significant observable deterrent to foreign investment. Based on their arguments, it seems implausible to argue that the limited international diversification of portfolios is due only to observable barriers to international investment, at least for the industrialized countries. It seems also improbable that the threat of the imposition of barriers could account for the existing portfolio allocations. If investors 
felt that there is some small probability that they might have trouble repatriating their holdings, the expected return on their foreign shares would be lower than the expected return for residents. As long as this political risk does not materialize, investors will look like they are insufficiently diversified internationally. A problem with this argument is that money markets seem well-integrated at short maturities and hence do not reflect potential political risks. Hence, to make the political risk argument convincing, one has to provide a rationale why foreign investors would be more at risk with equities than with short-term money market instruments.

If barriers to international investment cannot alone explain the limited diversification within industrialized countries, what can? It may well be that no single factor explains this limited diversification, but that many factors together succeed in explaining it. One possibility is that investors do not rank portfolios according to their mean retum and variance of retum. They might tailor their asset holdings to hedge against changes in variables that matter to them. ${ }^{3}$ For instance, they might want to hold a portfolio that is hedged against unanticipated changes in the purchasing power of their currency, that has a return negatively correlated with the return to their human capital, or that has a retum that is correlated with the spot rate of interest. One can think of many variables that affect an investor's expected utility and hence might affect her portfolio. In a setting where investors hedge against unanticipated changes in state variables, it may well be that limited diversification is optimal even though markets are fully integrated internationally. However, hedging against state variables often seems to imply that investors should have portfolios overweighted in foreign securities rather than in domestic securities. For instance, it would seem more likely that foreign securities have returns negatively correlated with the returns to human capital and with the purchasing power of the investor's domestic currency. Cooper and Kaplanis (1994) show, for instance, that hedging purchasing power risks cannot explain the home bias. Using a fully specified general equilibrium

${ }^{3}$ Stulz (1981a) argues that investors' desire to hedge against unanticipated changes in their consumption and investment opportunities might lead to a home bias. 
model, Uppal (1993) provides a model where a home bias emerges only if risk aversion is low. If investors are more risk-averse than investors with logarithmic utility as one would expect, his model predicts a reverse home bias. Finally, Baxter and Jermann (1993) and Baxter, Jermann, King (1994) argue that taking into account the return to human capital should lead U.S. investors to be short in the U.S. market portfolio of traded securities because the return to human capital are so highly correlated with the retum to the U.S. market portfolio of traded securities.

The last avenue of research for explaining the home bias assumes that investors from different countries have different predictive distributions for stock retums. French and Poterba (1990) argue that the holdings of Japanese investors in the U.S. and the holdings of U.S. investors in Japan could be understood if Japanese investors are substantially more optimistic about the expected return of Japanese shares than American investors. Shiller, Kon-ya and Tsutsui (1990) provide some survey evidence consistent with the view that investors are more optimistic about their own market relative to foreign investors. An alternative approach to generate different predictive distributions is to assume that the information sets of domestic and foreign investors differ in such a way that resident investors typically know more about a security than foreign investors. ${ }^{4}$ Such an approach implies that holding foreign securities is riskier than holding domestic securities provided that the risks associated with the existence of information asymmetries are not diversifiable and provided that, in equilibrium, prices are not fully revealing.

${ }^{4}$ Gehrig (1993) develops a two-period two risky assets noisy rational expectations equilibrium where a home bias emerges. Low (1993) has a continuous-time model where investors are asymmetrically informed and a home bias results. Brennan and Cao (1995) have an intertemporal noisy rational expectations model which has a home bias and also makes predictions about capital flows. Although not studying the home bias, Zhou (1994) provides a dynamic noisy rational expectations model where some investors know more about one stock and others know more about another stock. 


\section{Section 3. A simple model of portfolio choice in a foreign country.}

In this section, we provide a simple model to show the implications of existing models of international portfolio choice for holdings of securities by foreign investors in the domestic country. We assume away foreign exchange risk since it cannot be an explanation for the home bias. ${ }^{5}$ We also assume that all investors can borrow or lend at the domestic risk-free rate $\mathbf{R}$, so that money markets are internationally integrated. To simplify the analysis further, we assume that (A1) there are only two countries, the domestic country and the foreign country, (A2) domestic and foreign securities are uncorrelated, (A3) security prices follow lognormal diffusions with constant drift vector $\mu+R$ and variance-covariance matrix $V$, and (A4) all investors have the same logarithmic utility function. With our assumption that investors have logarithmic utility functions, no hedging motive arises for asset holdings.

Since we assume that security returns are uncorrelated across countries and that all investors have the same utility function, the portfolio of domestic securities held by investors in the absence of barriers to international investment is:

$$
w=\frac{V^{-1} \mu}{l^{\prime} V^{-1} \mu}
$$

where $w$ is the portfolio of domestic securities held by all investors. In the absence of barriers to international investment, all investors hold the same portfolio of domestic risky securities and that portfolio must therefore be the market portfolio of domestic risky securities.

We now consider the impact on the portfolio of domestic securities held by foreign investors of three types of barriers to international investment discussed in the literature formally or informally. Since Tesar and Werner (1995) document that foreign investors trade more than domestic

\footnotetext{
5 Foreign exchange risk can be eliminated through hedging cheaply for large holdings of securities from the major equity markets. Hence, if foreign exchange risk is an obstacle to internation diversification, one would expect investors to invest in mutual funds hedged against foreign exchange risk.
} 
investors, differential transaction costs do not seem to be a significant barrier to international investment and we therefore ignore this possibility in the following analysis.

The first type of barriers we consider is a fixed lump sum dissipative cost that has to be paid before a foreign investor can invest in the domestic country. This might be a knowledge acquisition cost, such that the foreign investor has to learn about domestic securities before she can invest in them. If this cost is the same for all foreign investors and does not depend on the amount invested, the investors with low wealth will choose not to invest in the domestic country because the benefits of international diversification are not sufficient to compensate them for the acquisition cost. To see this, note that a foreign investor can invest in domestic securities and by doing so can, for a given volatility of invested wealth, increase the expected return on her portfolio. This increase in expected return has to be balanced against the fixed cost that has to be paid to invest in the domestic country. For some investors, the net gain from investing in the domestic country will be negative. If a foreign investor invests in the domestic country, the fixed cost is sunk and she holds the domestic market portfolio. Consequently:

Proposition 1 (Sunk cost model). With a fixed cost of investing in the domestic country, there is a threshold level of wealth, $W^{*}$, such that foreign investors with wealth $W>W^{*}$ invest in the domestic country and the other foreign investors do not.

The second type of barriers to international investment we consider is the one modelled in Stulz (1981b). In that paper, investors suffer a deadweight cost on their foreign investments that is proportional to the amount invested. The deadweight cost for short positions may differ from the deadweight cost for long positions. Since Japan prohibits short-sales for foreign investors, we assume here that the deadweight loss for short positions is infinite and that the deadweight loss on long positions is c per dollar invested. With such a deadweight loss, some securities may not be held by 
foreign investors. These securities will be the ones where the diversification benefit from holding them does not compensate the investor for the deadweight cost. In the case where the deadweight cost is such that foreign investors invest in all domestic securities, then the optimal portfolio of domestic securities for domestic investors, $w_{d}$, and the optimal portfolio of these securities for foreign investors, $w_{f}$, are given by:

$$
\begin{aligned}
& w_{d}=\frac{V^{-1} \mu}{l^{\prime} V^{-1} l} \\
& w_{f}=\frac{V^{-1}(\mu-c l)}{l^{\prime} V^{-1}(\mu-c l)}
\end{aligned}
$$

The portfolio held by domestic investors is the tangency portfolio in mean-variance space. Foreign investors do not hold that portfolio because they face deadweight costs that are proportionately more onerous for securities that have low expected returns. The following result holds in this case:

Proposition 2 (Deadweight cost model). The expected return on the portfolio of domestic securities held by foreign investors gross of deadweight costs is greater than the expected return on the portfolio of domestic securities held by domestic investors. Further, if foreign investors hold positive amounts of all domestic securities, then their portfolio of domestic securities has more of security i than the portfolio of domestic investors if security i's weight in the tangency portfolio is greater than in the minimum variance portfolio of domestic securities.

Rudd (1977) and Roll and Ross (1977) show that it is difficult to obtain qualitative results about the investment proportions in efficient portfolios, even for the minimum-variance portfolio. Nevertheless, the minimum-variance portfolio must have smaller holdings of some securities with high expected returns than the tangency portfolio and larger holdings of other securities with low expected 
returns, since its expected return is lower than the tangency portfolio's expected return. To the extent that there is a size effect in expected returns, this would imply that foreign investors hold a portfolio more weighted towards small firms than domestic investors. The reason for this is straightforward. With barriers to international investment, stocks that have low expected excess returns eam no risk premium for foreign investors because their low expected excess returns are offset by the deadweight costs of holding these securities.

Lastly, we consider the case where foreign investors are less well informed than domestic investors about the distribution of the returns of domestic securities. In the extreme case where foreign investors can only use historical information to forecast returns and where domestic investors know the true distribution of the returns, we can use Williams (1977) to show that foreign investors use $((t+1) / t) \mathrm{V}$ as the variance-covariance matrix of their predictive distribution, where $t$ is the length of the period of time since the start of their sample. In a continuous-time setting, Williams (1977) shows that investors always know the true variance-covariance matrix but not the true expected return. In the case we consider, where the investment opportunity set is constant, investors eventually learn the true mean as they obtain more data. It would be possible to extend the analysis to the case where the true drift vector changes stochastically over time and reach similar results. ${ }^{6}$ At any point in time, though, investors' estimates of expected returns differ from the true expected returns. Since foreign investors' estimate of the expected returns are unbiased, the expected home bias resulting from this model is that foreign investors hold fewer domestic securities because they are more uncertain about the distribution of the returns of these securities than they are about the distribution of the returns of securities in their home country. However, it can be shown that:

\footnotetext{
${ }^{6}$ Low (1993) provides such an extension for the case where foreign investors can only hold the domestic market portfolio in the domestic country. See also Detemple (1986), Gennotte (1986) and Dothan and Feldman (1986) for results on portfolio selection in a one-country setting when investors have to learn about a stochastically changing drift vector.
} 
Proposition 3 (Asymmetric information model). If foreign investors have diffuse priors about domestic securities and form more precise priors using historical data only, they hold the same portfolio of domestic securities as domestic investors if these investors know the true distribution of returns.

To summarize, in this section we examined three different models that lead to a home bias. The sunk cost and the asymmetric information models predict that foreign and domestic investors hold the same portfolio of domestic securities, whereas the deadweight cost model predicts that foreign investors hold a portfolio of domestic securities that has a greater expected return than the portfolio held by domestic investors.

\section{Section 4. The data.}

In Japan, shares are registered. This makes it possible for a firm to know the distribution of the ownership of its shares among various categories of owners. Since there are (nonbinding) restrictions on foreign ownership, foreign owners of shares form a category of shareholders. Firms report foreign ownership, and it can be collected from annual reports and stock guides. This ownership data is available from the Pacific-Basin Capital Market Research Center (PACAP) files. In this paper, we use the data reported on these files, which is available from 1975 to 1991. For each firm, it provides foreign ownership as of the end of the fiscal year (which is March 31 for many Japanese firms).

Table 1 provides a summary of our data. In the second column, we show for each year the number of firms for which foreign ownership data is available and the number of firms for which foreign ownership or market value of equity data is missing from the files. It is immediately apparent that the proportion of firms for which data are missing falls steadily throughout our sample period. In the last sample year, 1991, we have data for 1452 firms and 13 firms have missing data. In 
Table 1

Equally- and value-weighted foreign ownership for nonfinancial Japanese firms by year.

\begin{tabular}{|c|c|c|c|}
\hline Year & $\begin{array}{l}\text { Sample size } \\
\text { (missing) }\end{array}$ & $\begin{array}{l}\text { Equally-weighted } \\
\text { foreign ownership }\end{array}$ & $\begin{array}{l}\text { Value-weighted } \\
\text { foreign ownership }\end{array}$ \\
\hline 1975 & $\begin{array}{c}868 \\
(385)\end{array}$ & $2.46 \%$ & $4.64 \%$ \\
\hline 1976 & $\begin{array}{c}988 \\
(267)\end{array}$ & 2.34 & 4.47 \\
\hline 1977 & $\begin{array}{l}1014 \\
(250)\end{array}$ & 2.36 & 4.02 \\
\hline 1978 & $\begin{array}{l}1043 \\
(230)\end{array}$ & 2.35 & 3.39 \\
\hline 1979 & $\begin{array}{l}1089 \\
(191)\end{array}$ & 2.30 & 3.25 \\
\hline 1980 & $\begin{array}{l}1106 \\
(187)\end{array}$ & 2.73 & 4.80 \\
\hline 1981 & $\begin{array}{l}1113 \\
(204)\end{array}$ & 4.08 & 7.98 \\
\hline 1982 & $\begin{array}{l}1118 \\
(235)\end{array}$ & 4.45 & 8.80 \\
\hline 1983 & $\begin{array}{l}1144 \\
(251)\end{array}$ & 5.07 & 10.46 \\
\hline 1984 & $\begin{array}{l}1191 \\
(217)\end{array}$ & 5.76 & 11.31 \\
\hline 1985 & $\begin{array}{l}1308 \\
(109)\end{array}$ & 5.15 & 9.97 \\
\hline 1986 & $\begin{array}{l}1298 \\
(93)\end{array}$ & 5.17 & 8.97 \\
\hline 1987 & $\begin{array}{r}1268 \\
(77)\end{array}$ & 4.25 & 6.88 \\
\hline 1988 & $\begin{array}{r}1309 \\
(52)\end{array}$ & 3.77 & 4.50 \\
\hline 1989 & $\begin{array}{c}1341 \\
(82)\end{array}$ & 3.71 & 5.02 \\
\hline 1990 & $\begin{array}{r}1426 \\
(29)\end{array}$ & 3.99 & 4.76 \\
\hline 1991 & $\begin{array}{r}1452 \\
(13)\end{array}$ & 4.02 & 5.59 \\
\hline Average & 17 & 3.76 & 6.40 \\
\hline
\end{tabular}

a Missing means the number of observations in which foreign ownership or market value of equity is not available at the end of the fiscal year. 
contrast, in the first sample year, 1975, we have data for 868 firms and missing data for 385 firms. To obtain summary statistics of foreign ownership, one could proceed in at least two different ways. First, one could compute the percentage of shares owned by foreign investors for each firm and construct an equally-weighted average. This number is given for each year in the third column. The equally-weighted measure of foreign ownership is quite small. It never exceeds $6 \%$. It exhibits a humped-shaped pattern: foreign ownership first increases and then falls, reaching a peak in 1984 . This humped-shaped pattern is also documented by French and Poterba (1990) based on aggregated Tokyo Stock Exchange data, and they argue that such a pattern is especially puzzling in light of the fact that barriers to international investment decrease throughout the 1980 s for investors wanting to invest in Japan. Second, one could add up the market capitalization of all the firms for which we have data and compute the market value of the shares held by foreign investors as a percentage of this market capitalization. We provide this measure in the last column of table 1 . The valueweighted measure of foreign ownership is always larger than the equally-weighted measure by at least $50 \%$. This difference reflects an important characteristic of the portfolios held by foreign investors that we will discuss throughout the paper: Foreign investors overweight large firms in their portfolios.

The firms with missing data are not included in the estimates of foreign investment reported in table 1. If these firms have more foreign investment than the firms used in that table, then we would be underestimating foreign investment. We found, however, that including the firms for which market value data is missing but foreign ownership data is available in our computations of the equally-weighted measure of foreign ownership would not change our conclusions. However, few firms have missing data in the last years of our sample period. Another issue with the data we use is that it could be the case that there are reporting errors or biases that lead some foreign investors to be counted as domestic investors and some domestic investors could be counted as foreign investors because they use a foreign vehicle to invest in Japan. We have no clear way of assessing the impor- 
tance of these biases. Finally, Japanese firms issued large amounts of convertible debt and debt with warrants offshore in the second half of the $1980 \mathrm{~s} .{ }^{7}$ It could be that the obstacles to holding offshore debt were smaller for foreign investors than the obstacles to holding domestic shares, so that foreign investors substituted offshore equity-linked debt for domestic shares. This substitution may play a role in the decrease in foreign ownership in the second half of the 1980 s documented in table 1.

Table 2 provides a different perspective on foreign ownership. Instead of looking at the whole market, we look at separate industries. For each industry, we report the difference between the industry's value-weighted foreign ownership and the overall value-weighted ownership. There are striking patterns of foreign ownership across industries. Throughout our sample period, foreign investors overweight the manufacturing sector every year, underweight the utilities sector every year and underweight the services sector every year but one. Surprisingly, they underweight the real estate sector every year for the first eight years of our sample and overweight it every year afterwards. A similar pattern holds for construction. Finally, the industry with the largest positive deviations of foreign ownership is agriculture, forestry, fishery and mining, where in 1979 , foreign investors hold a percentage of the industry almost three times the percentage they hold of the whole market. It is important to note, however, that the deviations for the agriculture, forestry, fishery and mining industry are surprisingly volatile. The data presented in this section show that there is substantial variation in foreign ownership both through time and across industries. It is especially clear from these data that foreign investors dramatically underweight regulated industries and have a bias towards manufacturing firms. For instance, in 1984, when foreign investors held $11.31 \%$ of the market, they own less than $2 \%$ of the transportation and communication industries' market capitalization and just about $2 \%$ of the electric power and gas industry.

\footnotetext{
${ }^{7}$ See Kang, Kim, Park and Stulz (1995) for an analysis of Japanese offshore issues.
} 
Table 2

Deviation of each industry's value-weighted foreign ownership from the overall value-weighted foreign ownership for nonfinancial Japanese firms by year and by industry. The sample size is in parenthesis.

\begin{tabular}{|c|c|c|c|c|c|c|c|c|}
\hline \multirow[b]{2}{*}{ Year } & \multicolumn{8}{|c|}{$\begin{array}{c}\text { Deviation of each industry's value-weighted foreign ownership from the overall } \\
\text { value-weighted foreign ownership }\end{array}$} \\
\hline & $\begin{array}{l}\text { Agricultur } \\
\text { Forestry, } \\
\text { Fishery } \\
\text { \& Mining }\end{array}$ & $\begin{array}{l}\text { Construc- } \\
\text { tion }\end{array}$ & $\begin{array}{l}\text { Manufact- } \\
\text { uring }\end{array}$ & $\begin{array}{l}\text { Whole- } \\
\text { sale } \\
\& \\
\text { Retail }\end{array}$ & $\begin{array}{l}\text { Real } \\
\text { Estate }\end{array}$ & $\begin{array}{l}\text { Transport- } \\
\text { ation \& } \\
\text { Communi- } \\
\text { cation }\end{array}$ & $\begin{array}{c}\text { Electric } \\
\text { power } \\
\& \\
\text { Gas }\end{array}$ & Services \\
\hline 1975 & $\begin{array}{c}3.10 \% \\
(15)\end{array}$ & $\begin{array}{c}-2.51 \% \\
(78)\end{array}$ & $\begin{array}{l}0.46 \% \\
(708)\end{array}$ & $\begin{array}{c}-1.38 \% \\
(67)\end{array}$ & N.A. & N.A. & N.A. & N.A. \\
\hline 1976 & $\begin{array}{c}2.75 \\
(14)\end{array}$ & $\begin{array}{r}-2.20 \\
(79)\end{array}$ & $\begin{array}{l}1.02 \\
(725)\end{array}$ & $\begin{array}{r}-0.53 \\
(71)\end{array}$ & $\begin{array}{r}-1.69 \\
(16)\end{array}$ & $\begin{array}{r}-4.11 \\
(48)\end{array}$ & $\begin{array}{r}-4.11 \\
(13)\end{array}$ & $\begin{array}{r}-2.37 \\
(22)\end{array}$ \\
\hline 1977 & $\begin{array}{l}0.88 \\
(14)\end{array}$ & $\begin{array}{r}-2.52 \\
(85)\end{array}$ & $\begin{array}{l}0.90 \\
(738)\end{array}$ & $\begin{array}{r}-0.33 \\
(72)\end{array}$ & $\begin{array}{r}-1.84 \\
(16)\end{array}$ & $\begin{array}{r}-3.26 \\
(53)\end{array}$ & $\begin{array}{r}-3.54 \\
(13)\end{array}$ & $\begin{array}{r}-1.46 \\
(23)\end{array}$ \\
\hline 1978 & $\begin{array}{c}2.97 \\
(14)\end{array}$ & $\begin{array}{r}-1.93 \\
(88)\end{array}$ & $\begin{array}{l}0.79 \\
(749)\end{array}$ & $\begin{array}{r}-0.86 \\
(83)\end{array}$ & $\begin{array}{r}-2.13 \\
(16)\end{array}$ & $\begin{array}{r}-2.90 \\
(56)\end{array}$ & $\begin{array}{r}-2.73 \\
(13)\end{array}$ & $\begin{array}{r}-0.53 \\
(24)\end{array}$ \\
\hline 1979 & $\begin{array}{c}6.05 \\
(14)\end{array}$ & $\begin{array}{r}-1.63 \\
(96)\end{array}$ & $\begin{array}{l}0.73 \\
(779)\end{array}$ & $\begin{array}{r}-0.84 \\
(89)\end{array}$ & $\begin{array}{r}-0.91 \\
(16)\end{array}$ & $\begin{array}{r}-2.85 \\
(56)\end{array}$ & $\begin{array}{r}-2.96 \\
(13)\end{array}$ & $\begin{array}{r}-0.19 \\
(26)\end{array}$ \\
\hline 1980 & $\begin{array}{c}5.07 \\
(15)\end{array}$ & $\begin{array}{l}-3.42 \\
(102)\end{array}$ & $\begin{array}{l}1.38 \\
(785)\end{array}$ & $\begin{array}{r}-2.96 \\
(93)\end{array}$ & $\begin{array}{r}-2.03 \\
(16)\end{array}$ & $\begin{array}{r}-4.31 \\
(57)\end{array}$ & $\begin{array}{r}-4.50 \\
(13)\end{array}$ & $\begin{array}{r}-0.51 \\
(25)\end{array}$ \\
\hline 1981 & $\begin{array}{r}-0.25 \\
(15)\end{array}$ & $\begin{array}{l}-5.21 \\
(100)\end{array}$ & $\begin{array}{l}1.86 \\
(793)\end{array}$ & $\begin{array}{r}-4.66 \\
(93)\end{array}$ & $\begin{array}{r}-3.55 \\
(15)\end{array}$ & $\begin{array}{r}-7.11 \\
(58)\end{array}$ & $\begin{array}{r}-7.28 \\
(14)\end{array}$ & $\begin{array}{r}-2.63 \\
(25)\end{array}$ \\
\hline 1982 & $\begin{array}{c}0.21 \\
(15)\end{array}$ & $\begin{array}{r}-4.17 \\
(99)\end{array}$ & $\begin{array}{l}1.85 \\
(793)\end{array}$ & $\begin{array}{r}-4.25 \\
(98)\end{array}$ & $\begin{array}{r}-1.59 \\
(16)\end{array}$ & $\begin{array}{r}-7.70 \\
(56)\end{array}$ & $\begin{array}{r}-7.97 \\
(14)\end{array}$ & $\begin{array}{r}-1.93 \\
(27)\end{array}$ \\
\hline 1983 & $\begin{array}{r}-1.64 \\
(15)\end{array}$ & $\begin{array}{l}-4.93 \\
(100)\end{array}$ & $\begin{array}{l}1.89 \\
(811)\end{array}$ & $\begin{array}{l}-5.13 \\
(102)\end{array}$ & $\begin{array}{r}-0.03 \\
(16)\end{array}$ & $\begin{array}{r}-8.91 \\
(57)\end{array}$ & $\begin{array}{r}-8.83 \\
(13)\end{array}$ & $\begin{array}{r}-3.05 \\
(30)\end{array}$ \\
\hline 1984 & $\begin{array}{r}-2.88 \\
(15)\end{array}$ & $\begin{array}{l}-5.96 \\
(104)\end{array}$ & $\begin{array}{l}1.86 \\
(846)\end{array}$ & $\begin{array}{c}-4.73 \\
(107)\end{array}$ & $\begin{array}{r}0.40 \\
(17)\end{array}$ & $\begin{array}{r}-9.56 \\
(58)\end{array}$ & $\begin{array}{r}-9.35 \\
(13)\end{array}$ & $\begin{array}{r}-6.08 \\
(31)\end{array}$ \\
\hline 1985 & $\begin{array}{r}-2.60 \\
(15)\end{array}$ & $\begin{array}{l}-4.22 \\
(112)\end{array}$ & $\begin{array}{l}1.49 \\
(914)\end{array}$ & $\begin{array}{c}-2.78 \\
(125)\end{array}$ & $\begin{array}{c}3.12 \\
(19)\end{array}$ & $\begin{array}{r}-7.48 \\
(74)\end{array}$ & $\begin{array}{r}-7.52 \\
(15)\end{array}$ & $\begin{array}{r}-4.57 \\
(34)\end{array}$ \\
\hline 1986 & $\begin{array}{r}-3.01 \\
(15)\end{array}$ & $\begin{array}{c}-0.79 \\
(111)\end{array}$ & $\begin{array}{l}0.95 \\
(896)\end{array}$ & $\begin{array}{c}-0.69 \\
(130)\end{array}$ & $\begin{array}{r}4.34 \\
(19)\end{array}$ & $\begin{array}{r}-5.24 \\
(77)\end{array}$ & $\begin{array}{r}-6.39 \\
(15)\end{array}$ & $\begin{array}{r}-2.33 \\
(35)\end{array}$ \\
\hline 1987 & $\begin{array}{r}0.54 \\
(14)\end{array}$ & $\begin{array}{c}1.81 \\
(105)\end{array}$ & $\begin{array}{l}0.69 \\
(864)\end{array}$ & $\begin{array}{l}0.26 \\
(140)\end{array}$ & $\begin{array}{r}4.96 \\
(18)\end{array}$ & $\begin{array}{r}-3.47 \\
(79)\end{array}$ & $\begin{array}{r}-5.37 \\
(15)\end{array}$ & $\begin{array}{r}-1.29 \\
(33)\end{array}$ \\
\hline 1988 & $\begin{array}{r}2.00 \\
(15)\end{array}$ & $\begin{array}{r}0.10 \\
(98)\end{array}$ & $\begin{array}{l}1.74 \\
(899)\end{array}$ & $\begin{array}{l}0.91 \\
(147)\end{array}$ & $\begin{array}{c}1.28 \\
(19)\end{array}$ & $\begin{array}{r}-3.84 \\
(76)\end{array}$ & $\begin{array}{r}-3.21 \\
(15)\end{array}$ & $\begin{array}{r}1.17 \\
(40)\end{array}$ \\
\hline 1989 & $\begin{array}{c}3.52 \\
(16)\end{array}$ & $\begin{array}{c}1.02 \\
(109)\end{array}$ & $\begin{array}{l}0.99 \\
(914)\end{array}$ & $\begin{array}{l}0.82 \\
(152)\end{array}$ & $\begin{array}{r}2.29 \\
(19)\end{array}$ & $\begin{array}{r}-3.73 \\
(78)\end{array}$ & $\begin{array}{r}-2.96 \\
(15)\end{array}$ & $\begin{array}{r}-0.05 \\
(38)\end{array}$ \\
\hline
\end{tabular}

(Table 2 continued) 
(Table 2 continued)

Deviation of each industry's value-weighted foreign ownership from the overall value-weighted foreign ownership

\begin{tabular}{|c|c|c|c|c|c|c|c|c|}
\hline Year & $\begin{array}{l}\text { Agriculture } \\
\text { Forestry, } \\
\text { Fishery } \\
\text { \& Mining }\end{array}$ & $\begin{array}{l}\text { Construc- } \\
\text { tion }\end{array}$ & $\begin{array}{l}\text { Manufact- } \\
\text { uring }\end{array}$ & $\begin{array}{l}\text { Whole- } \\
\text { sale } \\
\& \\
\text { Retail }\end{array}$ & $\begin{array}{l}\text { Real } \\
\text { Estate }\end{array}$ & $\begin{array}{l}\text { Transport- } \\
\text { ation \& } \\
\text { Communi- } \\
\text { cation }\end{array}$ & $\begin{array}{c}\text { Electric } \\
\text { power } \\
\& \\
\text { Gas }\end{array}$ & Services \\
\hline 1990 & $\begin{array}{r}2.81 \\
(16)\end{array}$ & $\begin{array}{c}0.49 \\
(115)\end{array}$ & $\begin{array}{l}1.01 \\
(981)\end{array}$ & $\begin{array}{l}0.30 \\
(156)\end{array}$ & $\begin{array}{r}1.99 \\
(20)\end{array}$ & $\begin{array}{r}-3.27 \\
(81)\end{array}$ & $\begin{array}{r}-2.85 \\
(15)\end{array}$ & $\begin{array}{r}-0.28 \\
(42)\end{array}$ \\
\hline 1991 & $\begin{array}{c}1.52 \\
(16)\end{array}$ & $\begin{array}{c}0.49 \\
(120)\end{array}$ & $\begin{array}{l}1.25 \\
(989)\end{array}$ & $\begin{array}{c}-0.26 \\
(160)\end{array}$ & $\begin{array}{c}1.65 \\
(23)\end{array}$ & $\begin{array}{r}-4.23 \\
(83)\end{array}$ & $\begin{array}{r}-3.40 \\
(15)\end{array}$ & $\begin{array}{r}-0.04 \\
(46)\end{array}$ \\
\hline Average & 1.24 & -2.09 & 1.23 & -1.59 & 0.39 & -5.12 & -5.18 & -1.63 \\
\hline
\end{tabular}

Section 5. Correlations between foreign ownership, firm characteristics, and individual ownership.

Table 3 presents a correlation matrix between foreign ownership, firm characteristics, and ownership by Japanese individual investors. Since we have a sample comprised of 17 years, we present the data as follows. First, for each year, we compute a correlation matrix using these variables. To insure that our results are not dominated by outliers, we focus on the Spearman rank correlation. The individual correlations reported in table 3 are the averages of yearly correlations. For each correlation coefficient, we report the number of estimates that are positive and the number that are negative. Further, we show for each coefficient the number of coefficients that are significantly positive at the 0.10 level and the number of coefficients that are significantly negative at the 0.10 level.

The results in table 3 are striking. For most of the variables considered, there is almost no variation in the sign of the correlation coefficients throughout our sample period and the correlation 
coefficients are almost always significant. We first consider the relations between accounting numbers and foreign ownership:

a) Leverage. Leverage is measured as the ratio of total liabilities and total assets. Every year in our sample period, there is a significant negative relation between leverage and foreign ownership. Since Japanese individual investors have holdings negatively correlated with leverage, it follows that institutional ownership must be positively correlated with leverage. The average coefficient for Japanese individual investors is about half the value for foreign investors, indicating that foreign ownership is more sensitive to leverage.

b) Current ratio. We use the current ratio, defined as the ratio of current assets to current liabilities, as a measure of short-run financial health of a firm. Foreign ownership as well as individual ownership are strongly positively related to the current ratio, but again the average correlation coefficient for Japanese individual ownership is smaller than the average correlation coefficient for foreign investors.

c) Return on assets. This measure of accounting performance is strongly positively correlated with foreign ownership. The correlation coefficient has an average of 0.317 , it is positive every year and significant at the 0.10 level every year also. For Japanese individual investors, the coefficient is 0.035 in contrast.

All three accounting numbers we look at indicate that foreign investors seek safety using traditional accounting criteria. Foreign investors hold more shares in firms that have low leverage, a high current ratio, and a high return on assets. Japanese individual investors follow the same pattern, but much less aggressively. In particular, the relation between Japanese individual investors' holdings and return on assets is positive for only 14 years and significantly so for only seven years.

We now turn to the data using market values: 
Table 3

Average of yearly Spearman correlation coefficients among several variables during the 1975-1991 period. ${ }^{a}$ Numbers in brackets are those of positive coefficients and those of negative coefficients, respectively. Numbers in parentheses are those of coefficients which are significantly positive and those of coefficients which are significantly negative at least at the 0.10 level, respectively.

\begin{tabular}{|c|c|c|c|c|c|c|c|c|c|c|}
\hline Variables & $\begin{array}{c}\text { Foreign } \\
\text { owner- } \\
\text { ship }\end{array}$ & $\begin{array}{l}\text { Leve- } \\
\text { rage }\end{array}$ & $\begin{array}{l}\text { Current } \\
\text { ratio }\end{array}$ & ROA & Beta & $\begin{array}{l}\text { Residual } \\
\text { variance }\end{array}$ & $\begin{array}{l}\text { Excess } \\
\text { return }\end{array}$ & $\begin{array}{l}\text { Book to } \\
\text { market }\end{array}$ & $\begin{array}{l}\log \\
\text { (MV) }\end{array}$ & $\begin{array}{l}\text { Individual } \\
\text { owner- } \\
\text { ship }\end{array}$ \\
\hline $\begin{array}{l}\text { Foreign } \\
\text { owner- } \\
\text { ship }\end{array}$ & 1.000 & $\begin{array}{l}-0.270 \\
{[0,17]} \\
(0,17)\end{array}$ & $\begin{array}{l}0.270 \\
{[17,0]} \\
(17,0)\end{array}$ & $\begin{array}{l}0.317 \\
{[17,0]} \\
(17,0)\end{array}$ & $\begin{array}{l}0.208 \\
{[16,0]} \\
(15,0)\end{array}$ & $\begin{array}{l}-0.168 \\
{[1,15]} \\
(1,15)\end{array}$ & $\begin{array}{l}0.086 \\
{[12,4]} \\
(7,3)\end{array}$ & $\begin{array}{l}-0.071 \\
{[6,11]} \\
(5,11)\end{array}$ & $\begin{array}{l}0.455 \\
{[17,0]} \\
(17,0)\end{array}$ & $\begin{array}{l}-0.135 \\
{[0,17]} \\
(0,13)\end{array}$ \\
\hline Leverage & & 1.000 & $\begin{array}{l}-0.685 \\
{[0,17]} \\
(0,17)\end{array}$ & $\begin{array}{l}-0.685 \\
{[0,17]} \\
(0,17)\end{array}$ & $\begin{array}{l}0.037 \\
{[11,5]} \\
(7,3)\end{array}$ & $\begin{array}{r}0.256 \\
{[16,0]} \\
(16,0)\end{array}$ & $\begin{array}{l}0.013 \\
{[8,8]} \\
(8,7)\end{array}$ & $\begin{array}{l}-0.295 \\
{[0,17]} \\
(0,17)\end{array}$ & $\begin{array}{l}-0.192 \\
{[0,17]} \\
(0,17)\end{array}$ & $\begin{array}{l}-0.148 \\
{[0,17]} \\
(0,17)\end{array}$ \\
\hline $\begin{array}{l}\text { Current } \\
\text { ratio }\end{array}$ & & & 1.000 & $\begin{array}{l}0.439 \\
{[17,0]} \\
(17,0)\end{array}$ & $\begin{array}{l}0.032 \\
{[12,4]} \\
(9,2)\end{array}$ & $\begin{array}{l}-0.163 \\
{[0,16]} \\
(0,16)\end{array}$ & $\begin{array}{l}-0.026 \\
{[7,9]} \\
(4,6)\end{array}$ & $\begin{array}{l}0.212 \\
{[17,0]} \\
(17,0)\end{array}$ & $\begin{array}{l}0.147 \\
{[17,0]} \\
(16,0)\end{array}$ & $\begin{array}{l}0.128 \\
{[17,0]} \\
(17,0)\end{array}$ \\
\hline ROA & & & & 1.000 & $\begin{array}{l}0.019 \\
{[9,7]} \\
(5,4)\end{array}$ & $\begin{array}{l}-0.190 \\
{[0,16]} \\
(0,15)\end{array}$ & $\begin{array}{l}0.113 \\
{[10,6]} \\
(9,2)\end{array}$ & $\begin{array}{l}0.033 \\
{[10,7]} \\
(7,4)\end{array}$ & $\begin{array}{l}0.224 \\
{[17,0]} \\
(17,0)\end{array}$ & $\begin{array}{c}0.035 \\
{[14,3]} \\
(7,0)\end{array}$ \\
\hline Beta & & & & & 1.000 & $\begin{array}{l}0.269 \\
{[16,0]} \\
(15,0)\end{array}$ & $\begin{array}{l}0.082 \\
{[12,4]} \\
(10,2)\end{array}$ & $\begin{array}{l}-0.210 \\
{[1,15]} \\
(0,15)\end{array}$ & $\begin{array}{l}0.254 \\
{[15,1]} \\
(15,0)\end{array}$ & $\begin{array}{r}-0.120 \\
{[1,15]} \\
(0,14)\end{array}$ \\
\hline $\begin{array}{l}\text { Residual } \\
\text { variance }\end{array}$ & & & & & & 1.000 & $\begin{array}{l}0.150 \\
{[14,2]} \\
(13,2)\end{array}$ & $\begin{array}{l}-0.306 \\
{[0,16]} \\
(0,16)\end{array}$ & $\begin{array}{l}-0.443 \\
{[0,16]} \\
(0,16)\end{array}$ & $\begin{array}{c}0.030 \\
{[12,4]} \\
(7,1)\end{array}$ \\
\hline $\begin{array}{l}\text { Excess } \\
\text { return }\end{array}$ & & & & & & & 1.000 & $\begin{array}{l}-0.248 \\
{[0,16]} \\
(0,16)\end{array}$ & $\begin{array}{l}0.055 \\
{[11,5]} \\
(8,4)\end{array}$ & $\begin{array}{r}-0.063 \\
{[3,13]} \\
(2,11)\end{array}$ \\
\hline $\begin{array}{l}\text { Book to } \\
\text { market }\end{array}$ & & & & & & & & 1.000 & $\begin{array}{l}-0.140 \\
{[2,15]} \\
(0,14)\end{array}$ & $\begin{array}{c}0.190 \\
{[17,0]} \\
(17,0)\end{array}$ \\
\hline $\log (\mathrm{MV})$ & & & & & & & & & 1.000 & $\begin{array}{l}-0.331 \\
{[0,17]} \\
(0,17)\end{array}$ \\
\hline $\begin{array}{l}\text { Individual } \\
\text { ownership }\end{array}$ & & & & & & & & & & 1.000 \\
\hline
\end{tabular}

a Firms with an extreme ROA (ROA larger than 1 or smaller than -1 ) are deleted. 
a) Beta. For beta, there is a sharp difference between foreign investors and Japanese individual shareholders. For 16 years, there is a positive correlation between foreign ownership and beta. In contrast, for 15 years there is a negative correlation between Japanese individual ownership and beta. Whereas foreign investors favor high beta stocks, Japanese individual investors prefer low beta stocks. To the extent that foreign investors expect high beta stocks to have higher expected returns, this result is supportive of the deadweight cost model.

b) Residual variance. Again, we find a sharp contrast between foreign investors and Japanese individual investors. For 15 years, there is a negative correlation between foreign ownership and residual variance. For 12 years, there is a positive correlation between individual ownership and residual variance.

c) Excess return. Foreign investors overweight the stocks that have done well but, as we will see later, some years they do the opposite. In contrast, Japanese individual investors tend to be contrarian, but again not every year.

d) Book to market. There is a negative relation between book to market and foreign ownership. However, the relation changes during our sample period, going from negative to positive in the later years of our sample. In contrast, for Japanese individual investors, the relation is positive and significant at the 0.10 level every year.

e) Market value. This is the strongest result. The average correlation coefficient between foreign ownership and market value is 0.455 . It is positive and significant at the 0.10 level every year. In contrast, the coefficient for Japanese individual investors is negative every year and significant at the 0.10 level every year. In words, foreign investors overweight large firms and Japanese individual investors overweight small firms. This result seems inconsistent with all three models discussed in section 3 .

Some additional comments on the numbers of Table 3 are useful at this point. First, it is important to note that the correlation between foreign ownership and firm size has economically 
meaningful implications for foreign ownership. If we divide firms in our sample in size quintiles every year and then average foreign ownership in quintiles across the sample period, we find the following means for foreign ownership going from the smallest firm quintile to the largest firm quintile: $1.21 \%, 2.38 \%, 3.32 \%, 4.94 \%$ and $6.97 \%$. Obviously, there is still a home bias when we focus on the largest firms, but it is smaller. Second, the correlations using market numbers we have just summarized suggest that foreign investors generally seek safety. They underweight small stocks and stocks of firms with large residual risk. Since firms with a low book to market would appear to be healthier firms, one would also expect foreign investors to overweight their portfolios towards those firms. They indeed do so, but not consistently. Finally, the fact that foreign investors underweight firms with low book-to-market ratios toward the end of our sample period is consistent with the behavioral explanation of French and Poterba (1991). If foreign investors are more pessimistic about the Japanese market than Japanese investors, one would expect foreign investors to underweight the stocks which have the highest valuation.

Since Japanese individual investors so strongly prefer small firms and high book-to-market firms, it comes as no surprise that there is a negative correlation between ownership by Japanese individual investors and ownership by foreign investors. However, this negative correlation is not close to minus one. This is not surprising since both foreign investors and Japanese individual investors value low leverage, a high current ratio and a high return on assets, suggesting that corporate investors must be underweighted in these shares.

\section{Section 6. Multivariate regression tests.}

In section 5, we showed that foreign ownership is correlated with firm characteristics. However, these firm characteristics are correlated among themselves, so that a multivariate regression approach is needed to have a better understanding of which firm characteristics significantly affect portfolio choice by foreign investors. We present the first set of results in table 4 . For these results, 
we proceeded as follows. Each year, we estimate a cross-sectional regression of foreign ownership in a firm on the eight explanatory variables. Note that if foreign investors hold the market portfolio of the domestic country, foreign ownership is the same in each firm and the coefficients of our cross-sectional multivariate regression should be insignificantly different from zero. Hence, these coefficients show how foreign investors depart from the market portfolio in their holdings. Rather than reproduce the coefficient estimates for each year, we aggregate them first for the whole sample period and then for two subsamples.

The first column of table 4 aggregates the coefficient estimates for 16 regressions. There is only one explanatory variable that has a significant coefficient each year, namely firm size. Each year, foreign investors invest more in large firms, controlling for seven other firm characteristics. The coefficient on leverage is significantly negative in 12 years out of 16 , indicating that foreign investors prefer firms with low leverage. There is a strong book-to-market effect in the first subperiod, but this effect weakens substantially in the second subperiod. In contrast, the return-on-assets effect is strong in the second half of the sample, but much less so in the first half. The other variables sometimes have significant coefficients, but they do not provide convincing results. The result that dominates table 4 is the importance of firm size in the investment decisions of foreign investors. One might be concerned that this reflects a reporting bias, in that the smaller firms might be more likely to have missing observations. However, if that were the case, one would expect the effect to falter in the second half of the sample and it does not.

Table 5 provides an alternative approach to estimating the relation between ownership and firm characteristics. The regressions in table 4 do not exploit the information contained in changes in ownership over time. One would expect that foreign ownership increases as firms become larger if indeed the relation between foreign ownership and firm size is not spurious. Table 5 provides regressions that use both cross-sectional and time-series data. The problem with this approach is that we are restricted to using the firms that have complete data for the whole period. Nevertheless, the 
Table 4

Regression estimates of foreign ownership on explanatory variables. Regression coefficients are the time-series average from year-by-year regressions for the 1976-1991 period. a Average t-statistics are in parentheses. Numbers in brackets are those of coefficients which are significantly positive at least at the 0.10 level and those of coefficients which are significantly negative at least at the 0.10 level, respectively.

\begin{tabular}{|c|c|c|c|}
\hline Variables & $\begin{array}{l}\text { Full period: } \\
\text { 1976-1991 }\end{array}$ & $\begin{array}{l}\text { Subperiod: } \\
1976-1983\end{array}$ & $\begin{array}{l}\text { Subperiod: } \\
\text { 1984-1991 }\end{array}$ \\
\hline \multirow[t]{2}{*}{ Intercept } & -0.0635 & -0.0370 & -0.0899 \\
\hline & $\begin{array}{r}(-2.19) \\
{[0,10]}\end{array}$ & $\begin{array}{c}(-1.09) \\
{[0,2]}\end{array}$ & $\begin{array}{c}(-3.29) \\
{[0,8]}\end{array}$ \\
\hline \multirow[t]{2}{*}{ Leverage } & -0.0397 & -0.0452 & -0.0342 \\
\hline & $\begin{array}{r}(-2.03) \\
{[0,12]}\end{array}$ & $\begin{array}{c}(-2.03) \\
{[0,6]}\end{array}$ & $\begin{array}{c}(-2.03) \\
{[0,6]}\end{array}$ \\
\hline \multirow[t]{2}{*}{ Current ratio } & 0.0017 & 0.0010 & 0.0024 \\
\hline & $\begin{array}{l}(0.48) \\
{[1,0]}\end{array}$ & $\begin{array}{l}(0.23) \\
{[0,0]}\end{array}$ & $\begin{array}{l}(0.74) \\
{[1,0]}\end{array}$ \\
\hline \multirow[t]{2}{*}{ ROA } & 0.1495 & 0.1683 & 0.1308 \\
\hline & $\begin{array}{l}(1.72) \\
{[8,0]}\end{array}$ & $\begin{array}{l}(1.69) \\
{[3,0]}\end{array}$ & $\begin{array}{l}(1.75) \\
{[5,0]}\end{array}$ \\
\hline \multirow[t]{2}{*}{ Beta } & 0.0025 & 0.0006 & 0.0044 \\
\hline & $\begin{array}{l}(0.61) \\
{[4,1]}\end{array}$ & $\begin{array}{l}(0.14) \\
{[1,0]}\end{array}$ & $\begin{array}{l}(1.07) \\
{[3,1]}\end{array}$ \\
\hline \multirow[t]{2}{*}{ Residual variance } & 6.7279 & 12.1359 & 1.3199 \\
\hline & $\begin{array}{l}(0.76) \\
{[4,0]}\end{array}$ & $\begin{array}{l}(1.41) \\
{[3,0]}\end{array}$ & $\begin{array}{l}(0.10) \\
{[1,0]}\end{array}$ \\
\hline \multirow[t]{2}{*}{ Excess return } & 0.0036 & 0.0049 & 0.0022 \\
\hline & $\begin{array}{l}(0.38) \\
{[4,3]}\end{array}$ & $\begin{array}{l}(0.45) \\
{[2,1]}\end{array}$ & $\begin{array}{l}(0.31) \\
{[2,2]}\end{array}$ \\
\hline \multirow[t]{2}{*}{ Book to market } & -0.0246 & -0.0390 & -0.0101 \\
\hline & $\begin{array}{r}(-2.10) \\
{[1,10]}\end{array}$ & $\begin{array}{c}(-3.28) \\
{[0,7]}\end{array}$ & $\begin{array}{c}(-0.93) \\
{[1,3]}\end{array}$ \\
\hline \multirow[t]{2}{*}{$\log (M V)$} & 0.0127 & 0.0114 & 0.0140 \\
\hline & $\begin{array}{c}(6.57) \\
{[16,0]}\end{array}$ & $\begin{array}{l}(5.22) \\
{[8,0]}\end{array}$ & $\begin{array}{l}(7.92) \\
{[8,0]}\end{array}$ \\
\hline
\end{tabular}

(Table 4 continued) 
(Table 4 continued)

\begin{tabular}{|c|c|c|c|}
\hline Variables & $\begin{array}{l}\text { Full period: } \\
\text { 1976-1991 }\end{array}$ & $\begin{array}{l}\text { Subperiod: } \\
1976-1983\end{array}$ & $\begin{array}{l}\text { Subperiod: } \\
\text { 1984-1991 }\end{array}$ \\
\hline Average sample size & 1122 & 993 & 1251 \\
\hline Average & 20.455 & 16.817 & 24.093 \\
\hline F-value & {$[16,0]$} & {$[8,0]$} & {$[8,0]$} \\
\hline $\begin{array}{l}\text { Average } \\
\text { adjusted } R^{2}\end{array}$ & 11.626 & 10.413 & 12.840 \\
\hline
\end{tabular}
equity are deleted 
Table 5

Time-series cross-section regression estimates of foreign ownership on explanatory variables. The Fuller-Battese method is used to estimate the model. Only 519 firms with complete data during the 1975-1991 period are used. t-statistics are in parentheses.

\begin{tabular}{|c|c|c|c|}
\hline Variables & $\begin{array}{l}\text { Full period: } \\
\text { 1976-1991 }\end{array}$ & $\begin{array}{l}\text { Subperiod: } \\
1976-1983\end{array}$ & $\begin{array}{l}\text { Subperiod: } \\
\text { 1984-1991 }\end{array}$ \\
\hline Intercept & $\begin{array}{l}-0.1715 \\
(-8.84)\end{array}$ & $\begin{array}{l}-0.1793 \\
(-6.57)\end{array}$ & $\begin{array}{l}-0.0684 \\
(-2.64)\end{array}$ \\
\hline Leverage & $\begin{array}{l}-0.0290 \\
(-3.82)\end{array}$ & $\begin{array}{l}-0.0803 \\
(-6.50)\end{array}$ & $\begin{array}{l}-0.0283 \\
(-2.62)\end{array}$ \\
\hline Current ratio & $\begin{array}{l}0.0010 \\
(1.37)\end{array}$ & $\begin{array}{l}0.0020 \\
(0.88)\end{array}$ & $\begin{array}{l}-0.0012 \\
(-1.53)\end{array}$ \\
\hline ROA & $\begin{array}{l}0.1023 \\
(4.30)\end{array}$ & $\begin{array}{l}0.0555 \\
(1.81)\end{array}$ & $\begin{array}{l}0.1717 \\
(5.42)\end{array}$ \\
\hline Beta & $\begin{array}{l}0.0029 \\
(3.28)\end{array}$ & $\begin{array}{l}-0.0007 \\
(-0.66)\end{array}$ & $\begin{array}{l}0.0069 \\
(5.48)\end{array}$ \\
\hline Residual variance & $\begin{array}{l}-2.3479 \\
(-1.33)\end{array}$ & $\begin{array}{l}2.2710 \\
(1.05)\end{array}$ & $\begin{array}{c}-11.5029 \\
(-4.85)\end{array}$ \\
\hline Excess return & $\begin{array}{l}0.0055 \\
(4.38)\end{array}$ & $\begin{array}{l}0.0021 \\
(1.33)\end{array}$ & $\begin{array}{c}0.0071 \\
(4.69)\end{array}$ \\
\hline Book to market & $\begin{array}{l}-0.0204 \\
(-5.46)\end{array}$ & $\begin{array}{l}-0.0122 \\
(-2.59)\end{array}$ & $\begin{array}{l}-0.0491 \\
(-8.37)\end{array}$ \\
\hline $\log (M V)$ & $\begin{array}{c}0.0221 \\
(16.17)\end{array}$ & $\begin{array}{c}0.0270 \\
(13.94)\end{array}$ & $\begin{array}{l}0.0136 \\
(7.54)\end{array}$ \\
\hline Root MSE & 3.566 & 2.861 & 3.175 \\
\hline
\end{tabular}


regressions in table 5 show again a strong effect of firm size on ownership. Leverage and book to market have significantly negative coefficients for the whole sample regression and the two subsample regressions and ROA has a significant positive coefficient for the three regressions. None of the other variables have coefficients that are significant in both subperiods. In contrast to table 4 , all coefficients in the second subperiod are significant except the one for the current ratio. In the second subperiod, beta and the excess return have significant positive coefficients and the residual variance has a significant negative coefficient.

Tables 6 and 7 show estimates of the regressions of tables 4 and 5 using Japanese individual ownership as the dependent variable. One generally would expect Japanese individual ownership to be related to firm characteristics in the opposite way of foreign ownership since deviations from the market portfolio by foreign investors have to be offset by opposite deviations by the other investors. However, it could be that what we observed so far reflects more the determinants of the holdings of shares by long-term Japanese corporate and bank shareholders, in which case individual ownership by Japanese shareholders would exhibit the same relationships with firm characteristics as the ownership by foreign shareholders. The coefficients that are estimated the most precisely in table 6 are the coefficients on leverage, residual variance, book to market and firm size. All these coefficients have the opposite sign than in table 4 except for the coefficient on leverage. Since both foreign ownership and individual ownership are negatively related to leverage, this implies that ownership by corporations and financial institutions must be strongly positively related to leverage. In contrast to foreign investors, individual investors invest more in small firms, firms with poor performance and firms with high book to market. Table 7, which uses both time-series and crosssection information, mostly confirms table 6 . 
Table 6

Regression estimates of individual ownership on explanatory variables. Regression coefficients are the time-series average from year-by-year regressions for the 1976-1991 period. ${ }^{\text {a }}$ Average $t-$ statistics are in parentheses. Numbers in brackets are those of coefficients which are significantly positive at least at the 0.10 level and those of coefficients which are significantly negative at least at the 0.10 level, respectively.

\begin{tabular}{|c|c|c|c|}
\hline Variables & $\begin{array}{l}\text { Full period: } \\
\text { 1976-1991 }\end{array}$ & $\begin{array}{l}\text { Subperiod: } \\
1976-1983\end{array}$ & $\begin{array}{l}\text { Subperiod: } \\
\text { 1984-1991 }\end{array}$ \\
\hline Intercept & $\begin{array}{c}0.8626 \\
(15.46) \\
{[16,0]}\end{array}$ & $\begin{array}{c}0.9558 \\
(14.88) \\
{[8,0]}\end{array}$ & $\begin{array}{c}0.7693 \\
(16.04) \\
{[8,0]}\end{array}$ \\
\hline Leverage & $\begin{array}{c}-0.1330 \\
(-3.78) \\
{[0,16]}\end{array}$ & $\begin{array}{c}-0.1534 \\
(-3.62) \\
{[0,8]}\end{array}$ & $\begin{array}{c}-0.1126 \\
(-3.93) \\
{[0,8]}\end{array}$ \\
\hline Current ratio & $\begin{array}{l}0.0111 \\
(1.28) \\
{[6,0]}\end{array}$ & $\begin{array}{l}0.0163 \\
(1.53) \\
{[3,0]}\end{array}$ & $\begin{array}{l}0.0059 \\
(1.04) \\
{[3,0]}\end{array}$ \\
\hline ROA & $\begin{array}{c}-0.1737 \\
(-1.19) \\
{[0,5]}\end{array}$ & $\begin{array}{c}-0.2455 \\
(-1.54) \\
{[0,3]}\end{array}$ & $\begin{array}{c}-0.1019 \\
(-0.83) \\
{[0,2]}\end{array}$ \\
\hline Beta & $\begin{array}{l}0.0070 \\
(0.91) \\
{[5,1]}\end{array}$ & $\begin{array}{l}0.0069 \\
(0.91) \\
{[3,1]}\end{array}$ & $\begin{array}{l}0.0071 \\
(0.91) \\
{[2,0]}\end{array}$ \\
\hline Residual variance & $\begin{array}{c}-38.9286 \\
(-3.07) \\
{[0,14]}\end{array}$ & $\begin{array}{c}-47.3595 \\
(-3.50) \\
{[0,7]}\end{array}$ & $\begin{array}{c}-30.4977 \\
(-2.64) \\
{[0,7]}\end{array}$ \\
\hline Excess retum & $\begin{array}{l}0.0108 \\
(0.86) \\
{[6,2]}\end{array}$ & $\begin{array}{l}0.0182 \\
(1.32) \\
{[4,1]}\end{array}$ & $\begin{array}{l}0.0033 \\
(0.41) \\
{[2,1]}\end{array}$ \\
\hline Book to market & $\begin{array}{l}0.0579 \\
(2.75) \\
{[11,1]}\end{array}$ & $\begin{array}{l}0.0754 \\
(3.61) \\
{[6,0]}\end{array}$ & $\begin{array}{l}0.0404 \\
(1.89) \\
{[5,1]}\end{array}$ \\
\hline $\log (\mathrm{MV})$ & $\begin{array}{c}-0.0448 \\
(-12.70) \\
{[0,16]}\end{array}$ & $\begin{array}{c}-0.0512 \\
(-12.80) \\
{[0,8]}\end{array}$ & $\begin{array}{c}-0.0384 \\
(-12.59) \\
{[0,8]}\end{array}$ \\
\hline
\end{tabular}

(Table 6 continued) 
(Table 6 continued)

\begin{tabular}{lllc}
\hline Variables & $\begin{array}{l}\text { Full period: } \\
1976-1991\end{array}$ & $\begin{array}{l}\text { Subperiod: } \\
1976-1983\end{array}$ & $\begin{array}{l}\text { Subperiod: } \\
1984-1991\end{array}$ \\
\hline Average sample size & 1178 & 1097 & 1259 \\
$\begin{array}{llll}\text { Average } \\
\text { F-value }\end{array}$ & 35.565 & 37.150 & 33.979 \\
$\begin{array}{l}\text { Average } \\
\text { adjusted } \mathrm{R}^{2}\end{array}$ & {$[16,0]$} & {$[8,0]$} & {$[8,0]$} \\
& 19.086 & 20.803 & 17.369 \\
\hline
\end{tabular}

a Firms with an extreme ROA (ROA larger than 1 or smaller than -1) and firms with negative book equity are deleted. 
Table 7

Time series cross section regression estimates of individual ownership on explanatory variables. The Fuller-Battese method is used to estimate the model. Only 519 firms with complete data during the 1975-1991 period are used. t-statistics are in parentheses.

\begin{tabular}{|c|c|c|c|}
\hline Variables & $\begin{array}{l}\text { Full period: } \\
\text { 1976-1991 }\end{array}$ & $\begin{array}{l}\text { Subperiod: } \\
1976-1983\end{array}$ & $\begin{array}{l}\text { Subperiod: } \\
\text { 1984-1991 }\end{array}$ \\
\hline Intercept & $\begin{array}{c}0.9141 \\
(32.22)\end{array}$ & $\begin{array}{c}0.9132 \\
(20.98)\end{array}$ & $\begin{array}{l}0.6548 \\
(20.56)\end{array}$ \\
\hline Leverage & $\begin{array}{l}-0.0756 \\
(-6.59)\end{array}$ & $\begin{array}{l}-0.0527 \\
(-2.74)\end{array}$ & $\begin{array}{l}-0.0216 \\
(-1.57)\end{array}$ \\
\hline Current ratio & $\begin{array}{l}-0.0050 \\
(-4.46)\end{array}$ & $\begin{array}{l}0.0084 \\
(2.37)\end{array}$ & $\begin{array}{l}-0.0023 \\
(-2.32)\end{array}$ \\
\hline ROA & $\begin{array}{l}-0.0835 \\
(-2.32)\end{array}$ & $\begin{array}{l}-0.1345 \\
(-2.89)\end{array}$ & $\begin{array}{l}-0.1198 \\
(-2.96)\end{array}$ \\
\hline Beta & $\begin{array}{l}0.0095 \\
(7.08)\end{array}$ & $\begin{array}{l}0.0063 \\
(3.81)\end{array}$ & $\begin{array}{l}0.0024 \\
(1.48)\end{array}$ \\
\hline Residual variance & $\begin{array}{l}-23.8239 \\
(-8.95)\end{array}$ & $\begin{array}{l}-11.4472 \\
(-3.49)\end{array}$ & $\begin{array}{l}-23.1450 \\
(-7.69)\end{array}$ \\
\hline Excess return & $\begin{array}{l}-0.0070 \\
(-3.71)\end{array}$ & $\begin{array}{l}-0.0058 \\
(-2.38)\end{array}$ & $\begin{array}{l}-0.0092 \\
(-4.73)\end{array}$ \\
\hline Book to market & $\begin{array}{c}0.0347 \\
(6.16)\end{array}$ & $\begin{array}{l}0.0140 \\
(1.91)\end{array}$ & $\begin{array}{c}0.0746 \\
(10.01)\end{array}$ \\
\hline $\log (\mathrm{MV})$ & $\begin{array}{l}-0.0513 \\
(-25.67)\end{array}$ & $\begin{array}{l}-0.0522 \\
(-16.90)\end{array}$ & $\begin{array}{l}-0.0342 \\
(-15.42)\end{array}$ \\
\hline Root MSE & 5.406 & 4.344 & 4.065 \\
\hline
\end{tabular}




\section{Section 7. Foreign trade and foreign ownership.}

Do foreign investors invest more in firms they may have heard of more? Merton (1987) argues that investors hold shares in firms which they know. Falkenstein (1995) shows that mutual funds hold more shares in firms that have a lot of news stories associated with them. A proxy for how well-known a firm is to foreign investors is the extent to which a firm exports. For a subset of firms (almost all manufacturing firms), we have export amounts made available by Daiwa Securities Co. that enable us to compute the ratio of exports to sales for the parent company. This data suffers from the fact that it does not have information for unconsolidated foreign subsidiaries. On average, this data is available for 678 firms per year. The average ratio of exports to sales is 0.1612 per year. Computing the correlation between foreign ownership and the exports ratio, we find an average correlation of 0.18 . This correlation is positive every year and significant at the 0.01 level for 16 years and at the 0.05 level for one year. It appears from these correlations that foreign investors invest more in firms that have a higher export ratio. However, larger firms are likely to have higher export ratios, so that the correlations might just reflect the correlation between size and foreign ownership documented earlier.

To separate the effect of the export ratio and the effect of size, we present in table 8 foreign ownership for size deciles and foreign trade deciles. Ignoring size, foreign ownership increases with the exports/sales ratio monotonically, going from $3.69 \%$ for the lowest exports/sales quintile to $5.71 \%$ for the largest. The impact of size is much larger, however, since foreign ownership is on average $1.80 \%$ for the smallest quintile and $7.66 \%$ for the largest quintile. Among the largest firms, the exports/sales ratio is uninformative: foreign ownership is $8.16 \%$ on average for the lowest quintile of the exports/sales ratio and $8.50 \%$ for the largest. In contrast, for small firms, foreign trade seems to affect foreign ownership. In particular, for the smallest size quintile, the firms in the smallest exports/sales quintile have average ownership of $1.03 \%$ and in the largest exports/sales 
Table 8

Mean and median foreign ownership (\%) by portfolios formed on market value of equity and then exports-to-sales ratio during the 1975-1991 period. Each year, the firms for which data is available on the exports-to-sales ratio are divided into size quintiles. Each quintile is then divided into five quintiles based on the exports-to-sales ratio. The cells in the table provide the time-series mean (median) of the yearly means (medians).

Size quintiles

\begin{tabular}{|c|c|c|c|c|c|c|}
\hline $\begin{array}{l}\text { Exports/ } \\
\text { Sales ratio }\end{array}$ & Smallest & 2 & 3 & 4 & Largest & All \\
\hline Smallest & $\begin{array}{c}1.03 \\
(0.96)\end{array}$ & $\begin{array}{c}2.63 \\
(2.85)\end{array}$ & $\begin{array}{c}3.39 \\
(3.36)\end{array}$ & $\begin{array}{c}4.87 \\
(5.04)\end{array}$ & $\begin{array}{c}8.16 \\
(9.62)\end{array}$ & $\begin{array}{c}3.69 \\
(3.84)\end{array}$ \\
\hline 2 & $\begin{array}{c}1.41 \\
(1.46)\end{array}$ & $\begin{array}{c}2.86 \\
(3.03)\end{array}$ & $\begin{array}{c}3.95 \\
(3.22)\end{array}$ & $\begin{array}{c}5.94 \\
(5.79)\end{array}$ & $\begin{array}{c}6.69 \\
(6.04)\end{array}$ & $\begin{array}{c}3.74 \\
(3.90)\end{array}$ \\
\hline 3 & $\begin{array}{c}2.26 \\
(2.55)\end{array}$ & $\begin{array}{c}2.44 \\
(2.25)\end{array}$ & $\begin{array}{c}3.99 \\
(4.34)\end{array}$ & $\begin{array}{c}5.09 \\
(4.15)\end{array}$ & $\begin{array}{c}7.73 \\
(5.92)\end{array}$ & $\begin{array}{c}4.10 \\
(3.81)\end{array}$ \\
\hline 4 & $\begin{array}{c}1.46 \\
(1.45)\end{array}$ & $\begin{array}{c}3.21 \\
(3.11)\end{array}$ & $\begin{array}{c}3.47 \\
(3.86)\end{array}$ & $\begin{array}{c}6.44 \\
(5.57)\end{array}$ & $\begin{array}{c}7.18 \\
(6.08)\end{array}$ & $\begin{array}{c}4.46 \\
(4.25)\end{array}$ \\
\hline Largest & $\begin{array}{c}2.82 \\
(2.78)\end{array}$ & $\begin{array}{c}4.15 \\
(3.62)\end{array}$ & $\begin{array}{c}4.17 \\
(4.30)\end{array}$ & $\begin{array}{c}4.72 \\
(4.26)\end{array}$ & $\begin{array}{c}8.50 \\
(8.68)\end{array}$ & $\begin{array}{c}5.71 \\
(5.68)\end{array}$ \\
\hline All & $\begin{array}{c}1.80 \\
(1.78)\end{array}$ & $\begin{array}{c}3.05 \\
(3.07)\end{array}$ & $\begin{array}{c}3.79 \\
(4.10) \\
\end{array}$ & $\begin{array}{c}5.41 \\
(5.15)\end{array}$ & $\begin{array}{c}7.66 \\
(6.83)\end{array}$ & \\
\hline
\end{tabular}


quintile average ownership is $2.82 \%$. There is therefore some evidence that foreign activities matter for foreign ownership if a firm is small but not if it is large. In constructing table 8, we ignored firms for which we have no export data. An alternative approach is to assume that these firms have no exports. If table 8 were constructed that way, the qualitative results would be similar, but the exports/sales ratio quintiles appear somewhat more related to foreign ownership. We re-estimated the regressions from tables 5 and 7 on the subsample of 263 companies for which we have export data every year. The exports-to-sales ratio has an insignificant coefficient in the foreign ownership regressions for the whole sample and the first half of the sample. It has a positive coefficient of 0.039 with a t-statistic of 2.32 for the second half of the sample, namely the period from 1984 to 1991. For the individual ownership regressions, the exports-to-sales ratio always has a significant negative coefficient.

\section{Section 8. The investment performance of foreign investors.}

Section 3 shows that barriers to international investment that take the form of a deadweight cost imply that the portfolio of domestic securities held by foreign investors should have a higher expected return than the portfolio held by domestic investors before taking into account the deadweight cost. Table 9 provides excess retums of foreign investors over the PACAP monthly valueweighted return. To construct the returns of foreign investors, we proceed as follows. For year $t$, we use ownership information at the end-of-fiscal year $t-1$. We use market value information as of the end of June of year $t$ to construct a portfolio that mimics holdings of foreign investors and then compute the monthly return on a portfolio with these weights for the next twelve months. Note that the excess returns for foreign investors are obtained by taking the difference of two Yen returns. They therefore have the interpretation of excess returns for foreign investors irrespective of their currency if the optimal currency hedge for Japanese securities is to short an amount of Yen equal to the price of the security. We investigated the correlation between Yen returns on the portfolio held 
by foreign investors and the Yen/Dollar exchange rate and found the correlation to be economically trivial and statistically insignificant, so that a hedge ratio of one is appropriate.

The procedure we use allows us to obtain returns for 16 years. Out of these 16 years, foreign investors underperform the value-weighted PACAP portfolio 9 times. Their average excess return relative to the value-weighted PACAP is negative over the whole sample period and in the second subsample period, which is the period from 1984 to 1991 . The 1984 to 1985 year plays a crucial role in this underperformance. For that year, foreign investors underperform the valueweighted PACAP portfolio by $1.28 \%$. Without that year, though, there is no underperformance in average returns, but the median excess return is still negative and foreign investors still underperform 8 years out of 15 . No case can be made that foreign investors choose a portfolio that has greater expected return than the market portfolio as one would expect if the explanation for the home bias is the existence of a proportional deadweight cost that applies to their investment in the foreign country.

\section{Section 9. Does foreign investment affect expected returns on domestic securities?}

The evidence presented in this paper shows that foreign investors increase the demand of some domestic securities relative to other domestic securities. One would expect that this differential demand affects expected returns. In this section, we investigate the relation between expected returns on domestic securities and the holdings of foreign investors. We proceed in the same way as Fama and French (1992) to find out whether foreign ownership is related to the cross-sectional variation in expected returns. Each month, we regress returns on foreign ownership. We use the same timing convention as we did earlier, namely we use the end of fiscal year t-1 ownership data for 12 months starting with July of year $t$. 
Table 9

Time-series average excess returns earned by foreign investors during the period 1976-1991 period. Excess return is the difference between value-weighted monthly returns of foreign investors (where the weight is Yen market value of each company held by foreign investors divided by total Yen market value held by foreign investors) and value-weighted PACAP monthly market returns. Foreign ownership is measured in fiscal year $\mathrm{t}-\mathrm{l}$ and market value is measured in June of year $\mathrm{t}$. These values are matched with returns for the months from July of year $t$ to June of year $t+1$. Medians are in parentheses.

\begin{tabular}{|c|c|}
\hline Period & Excess return \\
\hline $7607-7706$ & $-0.0699 \%$ \\
\hline $7707-7806$ & -0.3734 \\
\hline $7807-7906$ & 0.7072 \\
\hline $7907-8006$ & -0.1564 \\
\hline $8007-8106$ & 0.4017 \\
\hline $8107-8206$ & -0.6305 \\
\hline $8207-8306$ & 0.9495 \\
\hline $8307-8406$ & -0.7257 \\
\hline $8407-8506$ & -1.2831 \\
\hline $8507-8606$ & -0.2069 \\
\hline $8607-8706$ & -0.6993 \\
\hline $8707-8806$ & 0.4136 \\
\hline $8807-8906$ & 0.7365 \\
\hline 8907 - 9006 & 0.5461 \\
\hline 9007 - 9106 & 0.2565 \\
\hline $9107-9112$ & -0.3085 \\
\hline $7607-8406$ & $\begin{array}{c}0.0128 \\
(-0.1540)\end{array}$ \\
\hline $8407-9112$ & $\begin{array}{l}-0.0520 \\
(0.1249)\end{array}$ \\
\hline $7607-9112$ & $\begin{array}{c}-0.0190 \\
(-0.0490)\end{array}$ \\
\hline
\end{tabular}


We provide in table 10 the average slopes of the monthly regressions with $t$-statistics obtained from their time-series standard deviation. The average slope for the whole sample is negative but not significant. We also give the average slope obtained from regressions of returns on the log of market value. There is a size effect throughout our sample and it dominates the foreign ownership effect.

Wen we divide the sample in two subperiods, we find that the average slope for foreign ownership is insignificantly positive for the first subperiod and significantly negative for the second subperiod. There is no size effect in the first subperiod but there is a size effect in the second subperiod. When we allow both for an ownership effect and a size effect, the average coefficient on foreign ownership is not significant in the second subperiod and its absolute value falls by almost two-thirds. Our evidence shows that there are some traces of foreign ownership in returns. However, this effect seems weak and does not stand up when we allow for a size effect. Although from the perspective of forecasting expected returns it makes sense to allow for a size effect, the fact that foreign investors seem to have greater demand for large firm stocks may be a helpful clue in understanding why there is a size effect. We address this issue and related issues in the next section.

\section{Section 10. Modeling the home bias.}

The main finding of this paper is that foreign investors overweight shares of large firms and of firms with low leverage. This means that models of international portfolio allocation that seek to explain the home bias by variables that affect all shares in a country cannot explain our evidence. Future research that tries to explain the home bias has to explain both why foreign investors invest so little outside of their home country and why, when they invest abroad, they underweight smaller, riskier firms. In the U.S., it is often argued that informational asymmetries are more important for smaller firms. This is because larger firms disclose more information and are followed more actively by analysts and regulators. It may therefore be that foreign investors are less at a disadvantage rela- 
Table 10

Regression estimates of monthly returns on foreign ownership and market value of equity. Regression coefficients are the time-series average from month-by-month regressions for the 7607-9112 period, and t-statistics are the average coefficient divided by its time-series standard error. Foreign ownership is measured in fiscal year $t-1$ and market value is measured in June of year $t$. These values are matched with returns for the months from July of year $t$ to June of year $t+1$. Average $t-$ statistics are in parentheses.

Model

Foreign ownership

Log (market value)

Full period:

7607-9112

$($ Sample size $=186)$

$-0.0132$

$(-1.48)$

(2)

$-0.0025$

(3)

$-0.0010$

$-0.0025$

$(-0.12)$

$(-2.49)$

Subperiod:

7607-8406

$($ Sample size $=96)$

(0.02)

(5)

$-0.0019$

(6)

0.0084

$(-1.47)$

(1.07)

$-0.0020$

$(-1.58)$

Subperiod:

8406-9112

(Sample size $=90)$

$-0.02758$

$(-1.77)$

(8)

$-0.0032$

(9)

$-0.0111$

$(-0.73)$

$-0.0030$

$(-1.92)$ 
tive to domestic investors for large firms than for small firms. In particular, foreign investors who buy shares of small firms may be more likely to trade with informed, inside investors. In addition, large firms are more likely to be multinational firms and hence to disclose information in the home country of foreign investors.

None of the three simple models discussed in section 3 can explain the evidence presented in this paper. A straightforward extension of one of the models seems promising, however. Consider the model with information asymmetries. The version of the model we considered assumed that foreign investors have only historical data to form their predictive distribution over asset returns. If, instead, foreign investors have additional information that differs across securities, they no longer hold the tangency portfolio if the information they have differs from the information that domestic investors have. It seems reasonable to assume that foreign investors are less informed than domestic investors about all securities, but that this information asymmetry is larger for small firms than large firms. With such an assumption about information asymmetry, the portfolio held by foreign investors will be overweighted in large firms and foreign investors will exhibit a home bias. A simple way to implement this idea in the model with information asymmetries of section 3 is to assume that the variance-covariance matrix of the predictive distribution for foreign investors can be written as $\mathrm{HVH}$ where $\mathrm{H}$ is a diagonal matrix where the diagonal elements are given by a function $\mathrm{f}(\mathrm{MV})$, with $\mathrm{f}^{\prime}(\mathrm{MV}) \leq 0$, where MV is the market value of a firm's common stock. The upper-bound on $f(M V)$ is $(t+1) / t$. With this assumption, the optimal portfolio for foreign investors becomes:

$$
\mathrm{w}_{\mathrm{f}}=[\mathrm{HVH}]^{-1} \hat{\mu}
$$

This model leads to the following result:

Proposition 4 (Size-based informational asymmetry). If $\mathrm{H}>\mathrm{I}$ for foreign investors and $\mathrm{H}=$ I for domestic investors, there is an expected home bias and foreign investors are expected to over- 
weight large domestic firms in their portfolio provided that, for each $\mathrm{j}$, the predictive covariance of security j's return with the foreign investors' portfolio of domestic securities is greater than minus the predictive variance of that security $\mathrm{j}$ time it's portfolio weight.

Proof. Taking expectation of (3), we can replace the foreign investors' estimate of the drift vector with the true drift vector. For given $\mu$ and $V$, assuming $H=I$ for domestic investors, it follows from equation (3) that:

$$
\mathrm{HVHw}_{\mathrm{f}}=\mathrm{Vw}_{\mathrm{d}}=\mu
$$

Keeping expected returns unchanged, it follows that firm size and portfolio proportions must be negatively related for foreign investors since the derivative of the portfolio proportion for asset I, $\mathrm{w}_{\mathfrak{f}}$, is given by:

$$
-\left\{\sum_{j=1}^{j=n} H_{i i} V_{i j} H_{i j} w_{f j}+H_{i i} V_{i i} H_{i i} w_{f i}\right\} f^{\prime}\left(M V_{i}\right)>0
$$

The requirement on the covariance of security $i$ in the Proposition insures that the term in curly brackets is positive, which completes the proof since $\mathrm{f}^{\prime}\left(\mathrm{MV}_{\mathrm{i}}\right)$ is negative.

Proposition 4 delivers portfolio weights such that foreign investors overweight large domestic firms and such that they underweight the domestic portfolio. It would be surprising if information asymmetries alone could explain the magnitude of the home bias, but a model with the sunk cost described in section 3 and information asymmetries could be successful in explaining existing asset allocations described in this paper. Interestingly, such a model would be consistent with the greater turnover from foreign investors than from domestic investors emphasized by Tesar and Werner (1995) because foreign investors change their predictive distribution continuously. 


\section{Section 11. Conclusion.}

This paper provides evidence on the distribution of foreign share ownership in Japan from 1975 to 1991 . We confirm the existence of a substantial home bias using a different data source and show, further, that ownership by foreign investors is consistently and strongly biased against small firms. Existing models that are consistent with the existence of a home bias presented in section 3 are inconsistent with our evidence since these models predict either that foreign investors hold the market portfolio of a country or a portfolio overweighted towards high expected excess return securities. We show that a model in which foreign investors know more about large domestic than small domestic firms is consistent with the cross-sectional variation in ownership. Further research should investigate conditions under which a model based on informational asymmetries could explain both the level and the cross-sectional variation in foreign ownership documented here. 


\section{Bibliography}

Baxter, M., and U.J. Jermann, 1993, The international diversification puzzle is worse than you think, unpublished working paper, University of Virginia.

Baxter, M., U.J. Jermann, and R. King, Nontraded goods, nontraded factors, and international nondiversification, unpublished working paper, University of Virginia.

Brennan, M., and H.H. Cao, 1994, An informational model of international portfolio investment, unpublished working paper, University of California at Los Angeles.

Cooper, I.A., and E. Kaplanis, 1994, What explains the home bias in portfolio investment, Review of Financial Studies 7, 45-60.

Detemple, J.B., 1986, Asset pricing in a production economy with incomplete information, Journal of Finance 41, 383-392.

Dothan, U., and D. Feldman, 1986, Equilibrium interest rates and multiperiod bonds in a partially observable economy, Journal of Finance 41, 369-382.

Falkenstein, E.G., 1995, Preferences for stock characteristics as revealed by open-end mutual fund portfolio holdings, unpublished working paper.

Fama, E., and K.R. French, 1992, The cross-section of expected stock returns, Journal of Finance $47,427-466$.

French, K.R., and J.M. Poterba, 1990, Japanese and U.S. cross-border common stock investments, Journal of the Japanese and International Economies 4, 476-493.

French, K.R., and J.M. Poterba, 1991, Investor diversification and international equity markets, American Economic Review, Papers and Proceedings, 222-226.

Gennotte, G., 1986, Optimal portfolio choice under incomplete information, Journal of Finance 41, 733-746. 
Gehrig, T., 1993, An information based explanation of the domestic bias in international equity investment, The Scandinavian Journal of Economics 95, 97-109.

Kang, J.-K., Y.-C. Kim, K.-J. Park, and R.M. Stulz, 1995, An analysis of the wealth effects of Japanese offshore dollar-denominated convertible and warrant bond issues, Journal of Financial and Quantitative Analysis, forthcoming.

Low, A., 1993, Unpublished dissertation, University of California at Los Angeles.

Roll, R, and S.A. Ross, 1977, Comments on qualitative results for investment proportions, Joumal of Financial Economics 5, 259-265.

Rudd, A., 1977, A note on qualitative results for investment proportions, Journal of Financial Economics $5,265-269$.

Shiller, R.J., Kon-ya, F., and Y. Tsutsui, 1990, Speculative behavior in the stock markets: Evidence from the U.S. \& Japan, mimeo., Yale University.

Stulz, R.M., 198 la, A model of international asset pricing, Journal of Financial Economics 9, 383406.

Stulz, R.M., 1981b, On the effects of barriers to International investment, Journal of Finance 36, 923-934.

Stulz, R.M., and W. Wasserfallen, 1995, Foreign equity investment restrictions, capital flight restrictions and shareholder wealth: Theory and evidence, Review of Financial Studies, forthcoming.

Stulz, R.M., 1994, International portfolio choice and asset pricing: An integrative survey, NBER working paper.

Tesar, L., and I.M. Wemer, 1995, Home bias and high turnover, Journal of International Money and Finance, forthcoming.

Uppal, R., 1993, A general equilibrium model of international portfolio choices, Journal of Finance 48, 529-553. 
Williams, J.T., 1977, Capital asset prices with heterogeneous beliefs, Journal of Financial Economics $5,219-240$.

Zhou, G., 1994, Dynamic portfolio choice and asset pricing with heterogeneous information (II), unpublished working paper, Princeton University, Princeton, New Jersey. 